1115 Shift Happens: The Historical Institutionalism of Kathleen Thelen

1120 Nominations Accepted for the 2018 APSA Awards

1121 Highlights from $P S$ Political Science \& Politics Editors' Report, 2016-2017

1125 Meet the 2017-2018 Minority Fellows
11292017 Recipients of the Fund for Latino Scholarship

1131 Briefs

1132 Next in $P S$

1133 APSA Publishes New Book on Civic Engagement Education

1136 APSA Members of the Month

\title{
Shift Happens: The Historical Institutionalism of Kathleen Thelen
}

\author{
James Mahoney, Northwestern University
}

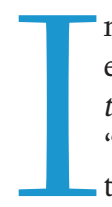

n 2010, Kathleen Thelen and I edited a book titled, Explaining Institutional Change. We nearly called it "shift happens," following a suggestion from Thelen's son, Andy. Someone talked us out of that title and although that was surely the right call for the book, I am now delighted to be able to take up Andy's suggestion. For the idea that "shift happens" not only provokes attention; it also captures the theoretical orientation of Thelen's work and the way in which she has promoted change within the discipline of political science itself.

The analytic core of nearly all of Thelen's work is a concern with the ways in which and the conditions under which institutions change, often gradually. In political science, she is the leading proponent of the view that adequately explaining institutional change requires grasping and analyzing incremental shifts in the rules that govern political behavior. She has been at the forefront of efforts to conceptualize different types of gradual institutional change, and she has done more than anyone else to formulate general and testable propositions about the variables that tend to produce one kind of gradual institutional change rather than another.

Thelen's work on institutional change has always been substantively oriented and historically grounded. The empirical matter of her research concerns central topics in the political economy of the advanced capitalist countries. A core thread running throughout her work is the role of sometimes shifting

James Mahoney is the Fulcher Professor of Political Science and Sociology at Northwestern University and chair of the department of sociology. He can be reached at james-mahoney@northwestern.edu.

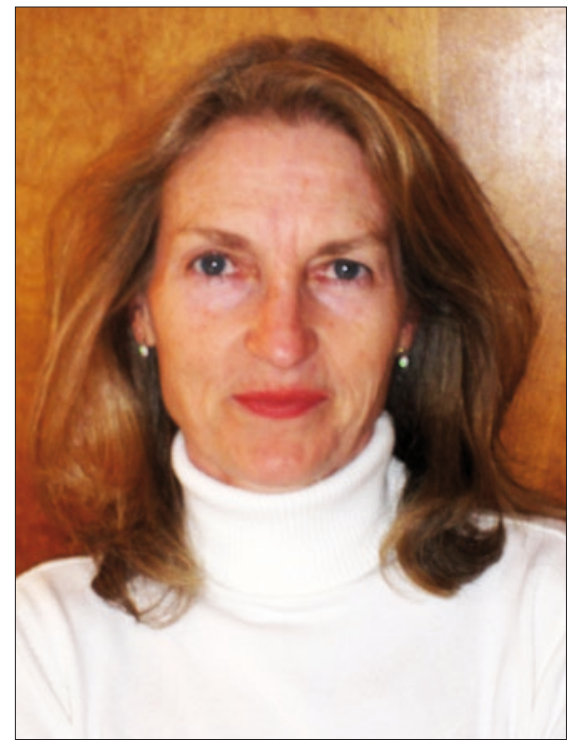

\section{7-2018 APSA President}

Kathleen Thelen

Ford Professor of Political Science,
Massachusetts Institute
of Technology

and evolving labor institutions in driving major political and social outcomes. Thelen is the author of three major substantive books: Union of Parts: Labor Politics in Postwar Germany (1991); How Institutions Evolve: The Political Economy of Skills in Germany, Britain, the United States, and Japan (2004); and Varieties of Liberalization and the New Politics of Social Solidarity (2014). Thelen completed these books while on the faculty of the departments of political science at Princeton University, Northwestern University, and MIT, respectively. The books illustrate how Thelen's substantive scope has expanded over time from a case study of Germany, to a small-N comparative analysis of four advanced capitalist countries, to a general comparative analysis with implications for capitalist countries in general.

Thelen's work also encompasses four major coedited books on theory, method, and approach in the fields of historical institutionalism and comparative-historical analysis. These books include the classic work Structuring Politics: Historical Institutionalism in Comparative Analysis (coedited with Sven Steinmo and Frank Longstreth, 1992), which first introduced historical institutionalism to political science. A Google search for "historical institutionalism" now yields more than 175,0oo results. Also included here is Beyond Continuity: Institutional Change in Advanced Political Economies (coedited with Wolfgang Streeck, 2005), which has been cited and referenced thousands of times. The other two books in this category are the coedited volumes Explaining InstitutionalChange: Ambiguity Agency and Power (2011) and Advances in Comparative-Historical Analysis (2015), which sought to redefine the frontiers of institutionalist and comparative-historical work.

Perhaps the ultimate test of the contribution of any individual scholar is to ask: What would the discipline look like without his or her work? In the case of Thelen, the counterfactual seems clear: the field of historical institutionalism would be greatly impoverished, substantively and analytically. Thelen helped create this field of study, and she has done as much as anyone to advance it. Empirically, much of what we know about the institutions that regulate labor-business relations, that govern skill formation, and that shape social solidarity is due to the work 
of Thelen. She has been at the very center of the political economy of labor relations, debates over the varieties of capitalism, and efforts to study the effects of institutions as mediating forces standing between globalization and labor outcomes. On the theoretical front, Thelen's work has done no less than set the agenda for debates about temporal analysis, including those surrounding the concepts of critical juncture and path dependence. In a world without Thelen, countless scholars would not now be carrying out highly fruitful work on the sources, nature, and consequences of gradual institutional change.

Thelen has helped to change political science in another way that will require us to consider her career from the standpoint of a talented woman working in a discipline that has historically been dominated by men. In the realm of gender equality in political science, gradual shift is occurring in political science on certain important dimensions. Understanding how Thelen's work and presence has been - and is-a force behind that shift helps situate her overall contribution.

\section{THE RISE OF HISTORICAL} INSTITUTIONALISM

The exact origins of the term "historical institutionalism" in political science remain obscure. We do know that the concept emerged in comparative politics with the volume Structuring Politics (1992), and it was originally proposed during a 1989 conference in Boulder, Colorado. The particular person who coined the label at that conference is unclear, however. Thelen recalls, "Sven [coeditor Sven Steinmo] and I were quite sure that either Theda Skocpol or Peter Hall had used this phrase at the workshop. We wanted to attribute it to the right person, but when we asked Theda and Peter, they both said, 'no it wasn't me."' Hall continues to believe that the most likely source of the label is Theda Skocpol; Skocpol in turn still suggests that the term might have first been used by Peter Hall. Thelen's coeditor Sven Steinmo sums up the situation as follows: "I can't say for sure the exact person who first articulated the term ... but I am sure that it grew out of the 'ether' in our workshop discussions in Boulder, Colorado, in 1989."

The atmosphere at Berkeley's political science department in the 1980s-while Thelen was a graduate student-was certainly conducive to historical-institutionalist work if not yet under that label. Thelen studied comparative political economy in the advanced industrial countries with John Zsyman, who chaired her dissertation. She was in one of
Zysman's courses with Jonas Pontusson, Sven Steinmo, Robin Gaster, and Tony Daley-all of whom strongly influenced her intellectually. Thelen recalls, "Most of them were a year or two further along than I was and generally knew a lot more about everything than I did. So they felt confident enough to give John a hard time for focusing on business and finance and downplaying labor. Robin, Tony, and Jonas all wrote dissertations on labor, and Sven-himself a skilled carpenterwrote his on tax policy in Sweden and the US. These four played a huge role in my graduate education." At the faculty level, Gregory Luebbert, Ernst Haas, Reinhard Bendix, and Harold Wilensky all figured prominently in Thelen's Berkeley experience.

Thelen's dissertation became the basis for her first book, Union of Parts (1991), a beautifully written and thoroughly researched analysis of labor relations in Germany during the tumultuous period of the 1970 s and 1980 os. Thelen identified the institutions that sustained the German version of "negotiated adjustment," which proved effective as a mode of managing economic change. In particular, she emphasized the interaction of centralized bargaining and works councils-the two tiers of Germany's dual system of labor relations-as the institutional basis for peaceful, negotiated adjustment in the midst of radical economic and political changes. As Wolfgang Streeck points out, this book set the tone for Thelen's future theoretical contributions and established her as a major authority on German politics and industrial relations. "Kathleen Thelen's exemplary career as a comparative political scientist began with a study of one case, Germany. Of this she developed a deep, congenial understanding through years of hard work, a grasp of German politics and institutions that is still unmatched. In fact herwork on Germany has enlightened an entire generation of German colleagues about their own country."

Thelen completed and published Union of Parts and Structuring Politics while an assistant professor in the department of politics at Princeton University. While here, her close colleague Nancy Bermeo recalls, "Kathy was a whirlwind of intellectual activity. Mirroring her intellectual concerns with solidarity and positive institutional change, she forged lasting links to colleagues of all sorts across the department. The breadth of her interests and her passion for understanding the way politics worked made her oblivious to preexisting divides based on method or subfield. The energy, intellect, and inclusiveness she showed even as an assistant professor make her an ideal leader for APSA."
It was also during her Princeton years that she forged strong bonds with colleagues at other institutions. Among the scholars who loomed largest in her intellectual development were Peter Hall, David Soskice, Torben Iversen, Wolfgang Streeck, and Peter Katzenstein. She characterizes her multiyear involvement in the workshops that Hall and Soskice convened in Berlin and Cambridge on "varieties of capitalism" as the most important formative experience of her career.

After moving to Northwestern University in 1994, Thelen wrote a sole-authored article, "Historical Institutionalism in Comparative Politics," for the Annual Review of Political Science (1999). The article instantly became a classic, and to date scholars have referenced it more than 7,00o times (according to Google Scholar). Thelen argued that the distinctive features of historical institutionalism were significantly rooted in its particular view of institutional origins and effects. Whereas rational choice theorists see institutions mainly as coordination mechanisms that can solve collective action problems, historical institutionalists see institutions as distributional instruments that emerge from and are implicated in power-laden and coalition-based conflicts over scarce resources. Thelen showed how this historical institutionalist view offers a basic alternative to equilibrium approaches. Notably, the historical institutional approach brings temporality into the picture by calling attention to: 1) the way in which the presumed stability of an institutional equilibrium state is predicated on nearly constant changes, coalitional shifts, and political maneuvers; and 2) the way in which the change of an institution may be gradual and piecemeal, even during a critical juncture, with many component parts remaining in place. With these insights, Thelen was able to show why political scientists cannot really separate the analysis of institutional stability from that of institutional change.

By this time, Thelen had become a "rising star" in political science and a leader in the field of historical institutionalism. At Northwestern, where she remained on the faculty until 2009, Thelen helped establish the department's reputation in political economy as well as comparative-historical analysis. For several years, she was a colleague with Michael Wallerstein and Peter Swenson, giving Northwestern a premier group of scholars focused on business-labor relations in advanced capitalist countries. At this time, Thelen also started offering graduate courses on institutionalism and 
institutional change, which were extremely popular among the students and which helped establish Northwestern as a stronghold for training in comparative-historical analysis. Her ties to sociologists were crucial to establishing an interdisciplinary group at Northwestern, the Comparative-Historical Social Science Workshop, which continues to thrive today. Ann Orloff recalls that she "was an indispensable part of the workshophelping us to build a wonderful community of political scientists and sociologists engaging our common concerns with the dynamics and mechanisms of political and social change." And Bruce Carruthers remembers that Thelen "was a model colleague and a pleasure to be around. Disciplinary boundaries didn't matter: it was all about creative and rigorous inquiry, animated by curiosity, tempered with evidence, and accompanied by warm collegiality."

Thelen became active on multiple advisory boards and in leadership roles in APSA sections, and she began presenting her work at a wide range of venues in Europe. She developed especially strong ties to Germany, becoming increasingly involved at the Max Planck Institute for the Study of Societies where she is now a permanent external member. It was here that she began her close and ongoing collaboration with then-institute director Wolfgang Streeck. She credits Streeck as having been a huge force in her intellectual development.

In the years since Thelen moved to MIT, Peter Hall has figured especially prominently as her closest colleague and intellectual comrade. She collaborates with him on "pretty much everything"-coteaching graduate seminars, jointly chairing a speaker series, convening workshops. She finds it "hard to imagine what my scholarly life in Cambridge would look like without Peter."

Anyone who has been a departmental colleague of Thelen can speak to her qualities of leadership and collegiality. She offers thoughtful, intelligent comments in discussions. She formulates original, realistic, and big ideas for going forward. She exhibits the highest levels of emotional intelligence, showing sensitivity to the interests and ideas of all parties. These qualities have allowed Thelen to enhance all of the organizations of which she has been a part.

\section{SETTING THE AGENDA: GRADUAL INSTITUTIONAL CHANGE}

Thelen's insight that institutional change and institutional stability are two sides of the same coin had significant implications for debates in comparative-historical analysis, including in both political science and sociology. This insight ran partly contrary to theories of punctuated equilibrium, critical junctures, and path dependence that were influential in political science by the late 1990s. Thelen viewed these frameworkswhen presented in certain strong formsas problematic for explaining the kinds of institutional change she observed in Germany and other advanced capitalist countries. "The notion of path dependence seems to encourage scholars to think of institutional change in one of two ways: as either very minor and more or less continuous (most of the time) or major but then abrupt and discontinuous (rarely)" (Thelen 2004, 28). By contrast, Thelen sought a framework that recognizes that "elements of stability and change are in fact inextricably intertwined" $(2004,31)$.

The problem with critical juncture and path dependence frameworks, then, is that they can be "both too contingent and too deterministic" (Thelen 1999, 385). They can be "too contingent in that the initial choice (call it a 'critical juncture') is seen as rather open and capable of being 'tipped' by small events or chance circumstances." As a corrective, Thelen emphasizes how "in politics this kind of blank slate is a rarity ... not all options are equally viable at any given point in time" (1999, 385). Path dependence frameworks also run the risk of being too deterministic on the backend of critical junctures, emphasizing as they often do the role of "lock-in" via increasing returns and positive feedback. As a corrective, Thelen argues, "Formal institutions do not survive long stretches of time by standing still. The language of stasis and inertia is particularly unhappy because as the world around institutions is changing their survival will not necessarily rest on the faithful reproduction of those institutions as originally constituted, but rather on their ongoing active adaptation to changes in the political and economic environment in which they are embedded" (2004, 293).

The breakthrough solution came with Thelen's work (2003; 2004) on a typology of types of gradual institutional change and its application to training systems and skill formation institutions in historical Germany, Britain, the United States, and Japan. In How Institutions Evolve, Thelen examines variations in the nineteenth century settlements between employers and skill-intensive workers, artisans, and early trade unions. She finds that the effects of these settlements were incremental, and can only be understood by making sense of specific types of longrun gradual change. For example, she discovered that German Handicraft Protection Law of 1897 , originally designed to shore up support among a reactionary artisanal class, was a historical cause of contemporary Germany's vocational training system. In analyzing this institution over time, Thelen discovered that it was often surprisingly resilient during enormous disruptions, including during the emergence of fascism. Throughout it all, the idea of a collectively managed system for monitoring how firms train workers persisted. Yet, the institutional arrangements were periodically renegotiated to bring institutions in line with changing social forces, which eventually shifted the basic purposes of the institution.

How Institutions Evolve was an enormous critical success, including as corecipient of APSA's Woodrow Wilson Foundation Award for the best book published in 2004 on government, politics, or international affairs. The ideas in the book inspired a new theoretical and empirical agenda for political science. And Thelen's next two coedited books advanced that agenda.

The edited book Beyond Continuity grew out of a working group on institutional change that Thelen and Wolfgang Streeck led at the Max Planck Institute in Germany. Scholars in the working group sought to make sense of the changes occurring in the political-economic institutions of rich democratic countries. Streeck and Thelen rejected the idea that these economies were converging on a single model, yet they also felt that the extent of change that was occurring was underappreciated. To capture the types of institutional change associated with liberalization, which they understood to be incremental in nature, Streeck and Thelen offered a radical new approach that conceptualized formal institutions as social regimes grounded in relations of authority, obligation, and enforcement. This vision of institutions not only allowed for a new typology of types of gradual institutional change in the advanced capitalist countries. It also called new attention to the role of the interpretation of rule meaning, the varied enforcement of rules, and the slippage in the enactment of social rules as potential sources of change. In fact, the framework showed that institutions often change not because of shifts in the formal rules of institutions. Rather, institutions often evolve because of changes in their interpretation, meaning, enforcement, and functions. 
Thelen and I tried to build on this agenda in our coedited book, Explaining Institutional Change. We were particularly concerned with developing hypotheses about the causes of different kinds of gradual change. Many of our ideas emerged organically from the explanations of institutional change in case study chapters in the book by Tulia Falleti, Ato Kwamena Onoma, Alan Jacobs, Dan Slater, and Adam Sheingate. At the structural level, the framework emphasized the interaction between features of the political environment and properties of institutions themselves. At the level of agency, the framework called attention to different changeagents and change-strategies that are likely to flourish in certain kinds of institutional settings. The theory is a good example of cumulative work, building on Thelen's prior contributions as well as the empirical work that had developed on institutional change in recent years.

The various themes of Thelen's scholarship come together magnificently in her 2014 book, Varieties of Liberalization and the New Politics of Social Solidarity, which received prizes from sections in both APSA and the American Sociological Association. Varieties makes fundamental empirical, theoretical, and normative contributions. Its starting point is the question of whether the pressures associated with deindustrialization and globalization will promote a general turn toward inegalitarianism and liberal market economies in the advanced capitalist countries. Its answer is that these pressures do not produce a single trajectory of change or common distributional pattern. Rather, depending on the social coalitions that are formed, countries follow one of three varieties of liberalization: deregulation, dualization, and embedded flexibilization. This three-fold typology captures core variations overlooked in dominant theories. The construction of this typology draws on insights that had been percolating in Thelen's work for decades: change is incremental; institutions are distributional instruments; the varieties of capitalism literature must be supplemented with a more dynamic approach; and the traditional welfare regimes of the advanced industrial countries might maintain their core logic even as political-economic institutions shift.

The book also raises questions about the extent to which these types can be linked to egalitarian capitalism. Here Thelen answers by emphasizing another one of her longstanding themes: the importance of shifting coalitions for institutional survival and adaption. She calls attention to the need for salaried groups, especially professionals and semiprofessionals, to make alliances with the more vulnerable segments of the working class. These alliances seem to imply interventions based above all on a social investment logic. And the state, through especially education and training programs, must play a leading role in promoting the social coalitions that could uphold the institutions of egalitarian capitalism in the future.

\section{PROMOTING GENDER EQUALITY IN POLITICAL SCIENCE}

In one sense, the central themes of Thelen's scholarship are traditionally "male" phenomena: labor and unions, vocational training and skill formation, and globalization and postindustrial change. Likewise, many of her collaborators have been men who work on traditional concerns in the field of comparative political economy (myself included). Yet, in another sense, Thelen's work has always bucked the theories and orientations favored by many male political scientists. And her efforts in calling attention to gender inequities and in promoting the careers of qualified women represent a mode of progressive action that has done much to chip away at male hegemony in the discipline.

Thelen has questioned the dominance in political science of fashionable theories and methods from economics-theories and methods that, not incidentally, are favored and used mostly by men. Beginning in the 1990s, she viewed with skepticism the idea that rational choice theory should serve as the principle theoretical basis for the study of institutions and for the analysis of substantive problems in the field of comparative politics (Thelen and Steinmo 1992; Thelen 1999). Instead, she emphasized that historical-institutionalism and rational-choice institutionalism are designed to ask and answer different questions. In the effort to explain real-world puzzles, historical institutionalists emphasize group actors and power, develop mid-range and macro-configurational generalizations, and examine temporal processes. While Thelen certainly advocates a place for rational actor models in political science, she is also clear that many of the big questions about political institutions require a dynamic, long-term temporal analysis.

More recently, Thelen has expressed concerns about the "revolution in causal inference" that is now sweeping through the discipline (Thelen and Mahoney 2015). Many political scientists-often male quantitative political scientists-have come to embrace a singular understanding of causation as the nearly exclusive way to conduct causal inference, which in turn they understand as the highest goal of social science. Thelen's position is not to dismiss work embedded in this tradition, including experimental research. Rather Thelen points out what is lost when political scientists treat one approach to causality as the singularly superior way to pursue research. She is concerned about a narrowing of the questions that are studied, a similar narrowing of the kinds of factors that can be studied as causally important, the downplaying of causal configurations and connections across different institutional realms, the failure to study causal mechanisms, the underappreciation of concept formation and theory building, the downplaying of long-run causal processes, and the inability to analyze temporal context in sophisticated ways.

In a recent work, Teele and Thelen (2017) show systematically that women are underrepresented in some of the discipline's top journals, even given their overall low share of appointments in the profession. Moreover, they find powerful evidence that suggests publication patterns are related to methodology in ways that are not gender neutral. Specifically, the underrepresentation of qualitative work (e.g., case studies and small-N work) in leading political science journals disadvantages women, who are more likely to carry out this kind of research.

Thelen's support for women in political science is perhaps most profound-though perhaps also least visible-in her assistance to individual scholars. I have been able to observe some of this often behind-the-scenes support. Thelen supports the best young scholars-which includes in good measures both men and women-by nominating their work for prizes, encouraging their book and article publications, and calling attention to their outstanding new work. Her former student Tulia Falleti recalls, "As a teacher, Kathy was dedicated, thorough, respectful, patient, and generous with her time and advice.... As a reader and dissertation advisor, she was one of the sharpest and most accurate critics I have ever had. Because she is a successful female scholar who has advanced our field in crucial theoretical and empirical ways, and because she is also a very kind human being, Kathy has been a role model for me since I first met her 21 years ago." We should not underestimate the importance of Thelen as a role model for junior women in the discipline. As Dawn Teele points out, "Kathy is a great advocate for women with children. She has been a tireless advocate for the idea 
that family and research career are compatible, but really only for us mere mortals if the institutions are there to make it possible." In fact, Thelen's advocacy on these issues has a long history. While at Princeton, Thelen worked on leave and tenure-clock extension policies for new parents. At Northwestern, Thelen says she "had the best possible mentor and partner in Jenny Mansbridge" in working on women's issues there.

Thelen has made women's advancement in political science a central theme in her presidency. She appointed a task force that consists of "a fantastic group of scholars working under the inspired leadership of Mala Htun and Frances Rosenbluth." The idea of the task force is first to identify the specific bottlenecks and special challenges that women scholars confront, and from there devise workable solutions, with the goal, as she puts it, of "making some policy moves that even if they are incremental, might prove transformative over the longer run"-thus helpful for the next generation of women political scientists.

\section{DISTINGUISHING FEATURES OF THELEN'S RESEARCH}

By focusing on gradual changes and employing contextualized comparisons, Thelen's scholarship opened a whole new gateway for insights about politics. Several features distinguish her work. First, Thelen's work produces counterintuitive findings about substantively important issues. Her gradualist perspective allows us to appreciate how small changes can add up to big institutional shifts and how in some cases institutions designed for one purpose may have different or even opposite downstream effects. This was the case with the German Handicraft Protection Law of 1897, and it was the case with Germany's dual system of labor relations in the 1970 and 1980 . Likewise, Thelen's contextualized approach yields surprising results that would be difficult to see without the lenses of historicalinstitutionalism. A striking recent example is her finding that moves toward liberalization may not undermine social solidarity as leading theories suggest, just as not all defenses of traditional economic institutions will enhance solidarity. Rather the effects of liberalization and resistance to liberalization depend on the institutional context and coalitional political dynamics they inspire.

Second, while historically grounded and focused on particular cases, Thelen's work on gradual change identifies general mechanisms with wide application in political science. For instance, the concepts of layering, conversion, drift, and displacement are designed to help analysts make sense of processes of institutional change in concrete historical cases. Yet these concepts refer to mechanisms that transcend individual cases and allow for systematic comparison across very different contexts. And they entail hypotheses about the sources and outcomes of institutional change that allow for explanatory generalizations across cases. Through the identification and use of general mechanisms, Thelen's work meets the dual promise of the best comparative-historical analysis: offering new insights about specific cases as well as broad theoretical lessons that transcend specific cases.

Finally, Thelen's gradualist perspective to research has large normative and political implications. Throughout her work, she has explored the roles and responsibilities of business and labor to creating or maintaining social solidarity and egalitarian capitalism. One practical upshot is that the two groups need each other: egalitarian capitalism cannot work without either effective employer coordination or high levels of labor organization and unity. In the current marketoriented period, the state must play a role in encouraging employer coordination and not undermining labor power. Yet, at the same time, the reproduction of institutions is not a matter of stasis or inertia: it depends on shifting the coalitional basis on which these institutions rest. As Thelen notes, perhaps the biggest normative and political issue that lies ahead concerns the fact that institutions that have traditionally benefitted blue-collar workers may not serve salaried workers, women, and low-skill workers in the same way. Institutional adaptation will be needed to forge new coalitions that incorporate nontraditional groups.

While the idea that "shift happens" captures important aspects of Kathleen Thelen's intellectual work, it is perhaps misleading in one way: It implies that change simply happens, as if random. Yet, as Thelen's work shows, gradual institutional shifts are typically the product of intentional actors, even if final outcomes sometimes reflect unintended consequences that do not match any actor's preferred choice. Likewise, intentionality rather than randomness is the appropriate frame for thinking about the change processes that Thelen has helped unleash in political science. She arrived at core insights about the ways in which shifting institutions can sustain solidarity and equalitarian outcomes by virtue of intensive work on individual cases, including especially Germany. To advance these ideas, she worked against the current of many mainstream theories in political science. She carved out a new set of orientations to help direct research on some of the most pressing problems in contemporary politics. As APSA now faces important challenges and opportunities, the association could not be in better in hands than with Kathleen Thelen at its leadership.

\section{R E F E R E N C E S}

Mahoney, James and Kathleen Thelen, eds. 2015. Advances in Comparative-Historical Analysis. New York: Cambridge University Press.

Mahoney, James and Kathleen Thelen, eds. 2010. Explaining Institutional Change: Ambiguity, Agency, and Power. New York: Cambridge University Press.

Steinmo, Sven, Kathleen Thelen, and Frank Longstreth, eds. 1992. Structuring Politics: Historical Institutionalism in Comparative Analysis. New York: Cambridge University Press.

Streeck, Wolfgang, and Kathleen Thelen. 2005. Beyond Continuity: Institutional Change in Advanced Political Economies. Oxford: Oxford University Press.

Teele, Dawn, and Kathleen Thelen. 2017. "Gender in the Journals." PS: Political Science \& Politics 50: 443-47.

Thelen, Kathleen. 1991. Union of Parts: Labor Politics in Postwar Germany. Ithaca, NY: Cornell University Press.

Thelen, Kathleen. 1993. "European Labor in Transition: Sweden and Germany Compared." World Politics 46: 23-49.

Thelen, Kathleen. 1994. "Beyond Corporatism: Toward a Framework for the Study of Labor in Advanced Capitalism." Comparative Politics 27.

Thelen, Kathleen. 1999. "Historical Institutionalism in Comparative Politics." Annual Review of Political Science Vol. 2. Palo Alto: Annual Reviews, Inc.

Thelen, Kathleen. 2001. "Varieties of Labor Politics in the Developed Democracies," in Varieties of Capitalism, ed. Peter A. Hall and D. Soskice. New York: Oxford University Press.

Thelen, Kathleen, and Christa van Wijnbergen. 2003. "The Paradox of Globalization: Labor Relations in Germany and Beyond." Comparative Political Studies 36: 859-80.

Thelen, Kathleen. 2004. How Institutions Evolve: The Political Economy of Skills in Germany, Britain, the United States, and Japan. New York: Cambridge University Press.

Thelen, Kathleen. 2014. Varieties of Liberalization and the New Politics of Social Solidarity. New York: Cambridge University Press.

Thelen, Kathleen, and James Mahoney. 2015. "Comparative-Historical Analysis in Contemporary Political Science," in Advances in Comparative-Historical Analysis, eds. James Mahoney and Kathleen Thelen. New York: Cambridge University Press.

Thelen, Kathleen, and Sven Steinmo. 1992. "Historical Institutionalism in Comparative Analysis," in Structuring Politics: Historical Institutionalism in Comparative Analysis, eds., Sven Steinmo, Kathleen Thelen, and Frank Longstreth, 1-32. New York: Cambridge University Press. 